\title{
FOREIGN TRADE: TRADE BALANCE DOWN DUE TO DECLINE IN EXPORT ${ }^{1}$
}

\author{
A.Knobel, A.Firanchuk
}

Russia's foreign trade turnover continued to fall in Q1 2016. Unlike 2015, exports fell at faster pace than imports. At the same time, the rouble exchange rate moved synchronously with imports for two straight years. The structure of exports saw a few (non-fuel) commodities change in terms of Russia's share of global markets. For example, the share of Russia's metals of EU imports shrank as the share of fertilizes hiked.

\section{Exports fell at faster pace}

In Q1 2016, exports and imports continued to fall (compared with Q1 2015), although trade volumes were small early in 2015 (Fig. 1). In value terms, in M3 2016 exports dropped to $\$ 59.3$ bn (by 65.7\% from 2015), imports fell to $\$ 35.8 \mathrm{bn}(85.1 \%)$, merchandise trade balance dropped by half to $\$ 23.5 \mathrm{bn}(48.8 \%)^{2}$. In January 2016 , export volumes declined in value due to a fall of global crude prices, but in March export volumes stabilized following a recovery of crude prices. However, crude prices in Q1 2016 were far below the prices seen in Q1 2015, and therefore exports dropped below volumes seen in 2015 (Fig. 1).

\section{Exchange rates and dynamics of trade turnover}

Note that the US dollar strengthened against other currencies in JanuaryFebruary 2016 (compared with January-February 2015). For example, the

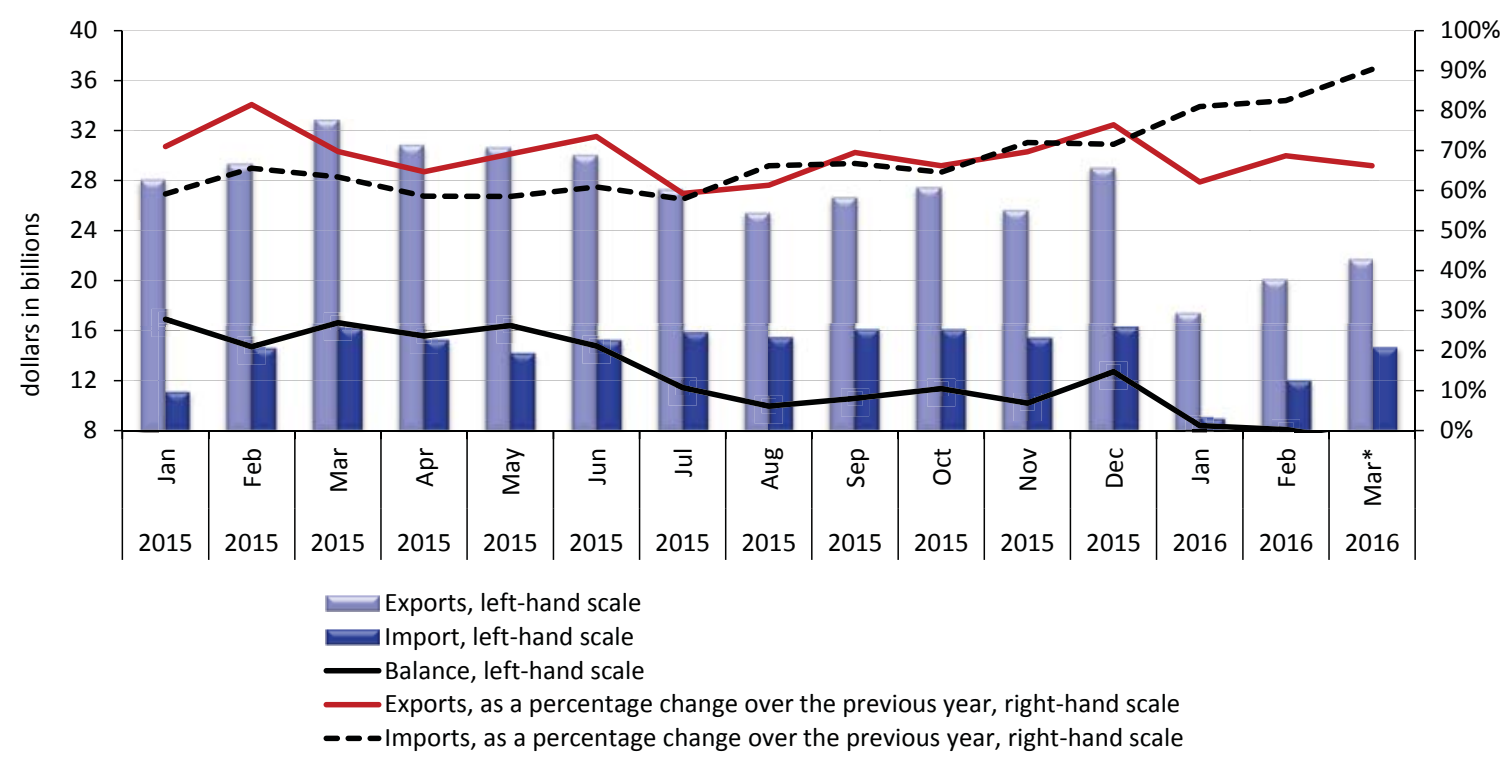

* calculated using the data released by Russia's Central Bank.

Source: own calculations using the data released by Russia's Federal Customs Service (FCS).

Fig. 1. Dynamics of Russia's foreign trade in 2015-2016

1 This paper was originally published in Online Monitoring of Russia's Economic Outlook No.6(24).

2 Preliminary data from Russia's Federal Customs Service (FCS) and Central Bank. 


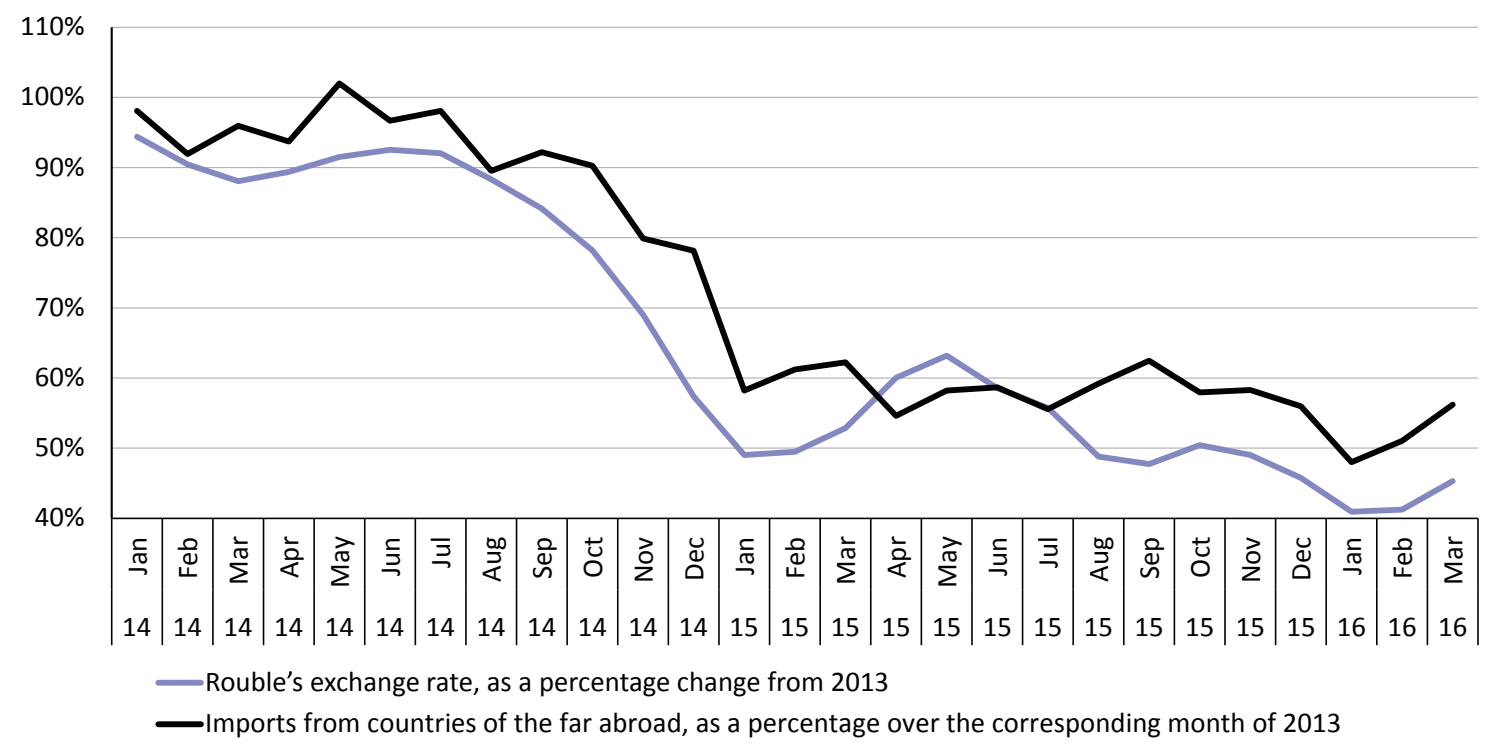

Source: own calculations using the data released by Russia's Federal Customs Service (FCS) and Central Bank ${ }^{1}$.

Fig. 2. Dynamics of Russia's importa and rouble's exchange rate in 2014-2016

fact that the rouble gained $4.5 \%$ over the euro explains only partially why Russia's trade volumes expressed in dollars contracted in early 2016.

In addition, the rouble exchange rate moved synchronously with volumes of imports from countries of the far abroad for more than two straight years (Fig. $2^{2}$ ). For instance, the $47 \%$ slump of the rouble to US dollar exchange rate in July 2014/January 2015 triggered a sharp fall of imports from countries of the far abroad (41\% of volumes seen in the same period of 2013). Imports stabilized as the rouble exchange rate rebounded in February-May 2015 (compared to the same period of 2013). Unlike early in 2015, the depreciation of the rouble since Q4 2015 gave rise to a new fall of imports.

In January-February 2016, the annualized ruble to US dollar exchange rate stood at about $83 \%$, and imports from countries of the far abroad were $82.9 \%$ from 2015. Additionally, in February-March 2016 the rouble's exchange rate rose with imports from countries of the far abroad. Thus, the rouble exchange rate still has a strong effect on the dynamics of imports.

\section{Russia's share of global commodities markets}

In 2015, exports of 'Metals and precious stones and articles thereof (FEACN 71-83)', the second after 'Mineral products (FEACN 25-27)', dropped to $78.5 \%$ from 2014 (although their share of total exports increased from $10.5 \%$ to $11.9 \%$ ). Additionally, highly variable global demand for, e.g., metals, poses a question of how the Russia's share of global exports has changed. Since no complete statistics on global trade are available, let's compare the dynamics of monetary values of exports of metals from Russia in 2015 with the dynamics of EU imports of metals. In 2015, monetary (in dollar terms) values of EU exports of metals from all countries (except EU member countries) dropped by an average of $11.7 \%$ while Russia's exports of metals to all

1 Average currency exchange rate in dollar terms in January-February 2016 compared to January-February 2015. Source: IMF, https://www.imf.org/external/np/fin/ert/GUI/Pages/ CountryDataBase.aspx

2 The rouble to US dollar exchange rate quoted by Russia's Central Bank: http://www.cbr. ru/currency_base/dynamics.aspx 
countries fell by $18.8 \%$ (Table 1). This suggests that total exports of metals from Russia sank deeper than global trade in metals ${ }^{1}$.

The reverse trend was observed as to, e.g., fertilizers: EU total imports of fertilizers dropped, whereas Russia's total exports of fertilizers edged up (in dollar terms).

Table 1

DYNAMICS OF RUSSIA'S EXPORTS AND EU IMPORTS OF CERTAIN GOODS, \%

\begin{tabular}{|c|c|c|c|c|c|}
\hline \multirow[b]{2}{*}{ Family of goods - FEACN code } & \multirow{2}{*}{ 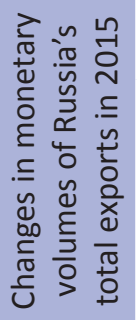 } & \multirow{2}{*}{ 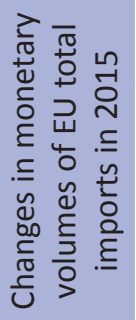 } & \multicolumn{3}{|c|}{$\begin{array}{c}\text { Russia's share of } \\
\text { EU imports }\end{array}$} \\
\hline & & & 2013 & 2014 & 2015 \\
\hline Ferrous metals - 72 & -25.8 & -14.9 & 17.1 & 15.7 & 15.9 \\
\hline $\begin{array}{l}\text { Articles made of fer- } \\
\text { rous metals }-73\end{array}$ & -26.4 & -8.9 & 1.1 & 1.2 & 0.9 \\
\hline Copper and articles thereof -74 & -8.9 & -13.2 & 10.5 & 11.6 & 17.1 \\
\hline Nickel and articles thereof - 75 & -33.8 & -17.4 & 20.5 & 20.4 & 17.3 \\
\hline $\begin{array}{l}\text { Aluminium and arti- } \\
\text { cles thereof }-76\end{array}$ & 9.9 & -7.4 & 7.3 & 11.7 & 11.1 \\
\hline Metals - 72-76 & -18.8 & -11.7 & 10.4 & 10.9 & 11.1 \\
\hline Nitrogenous fertilizers -3102 & -17.6 & -8.5 & 24.5 & 28.4 & 28.4 \\
\hline Potassic fertilizers -3104 & 9.5 & -15.0 & 26.4 & 40.6 & 46.7 \\
\hline Mixed fertilizers - 3105 & 6.0 & -4.3 & 43.1 & 32.6 & 36.2 \\
\hline Fertilizers & 1.5 & -7.9 & 32.5 & 32.0 & 34.2 \\
\hline
\end{tabular}

Sources: own calculations using the data released by Russia's Federal Customs Service (FCS) and Eurostat ${ }^{2}$.

1 This conclusion was made using incomplete data on global imports of metals and is preliminary.

2 http://ec.europa.eu/eurostat/web/international-trade/data/database 